\title{
Peran Serta Masyarakat Lokal Dalam Pengelolaan Daya Tarik Wisata Pura Goa Giri Putri Nusa Penida
}

Nyoman Andika Widiastraa,1, I Made Adikampanaa,2

1andikawidiastra@gmail.com, 2adikampana@unud.ac.id

a Program Studi S1 Destinasi Pariwisata, Fakultas Pariwisata,Universitas Udayana, Jl. Dr. R. Goris, Denpasar, Bali 80232 Indonesia

\section{Abstract}

This research is located in Pakraman Karang Sari, Village Office Suana, Nusa Penida in tourist attraction Pura Goa Giri Putri which aims to determine the function of local communities in the management of the attraction in the development and planning as a community-based tourism destination.

Data collection techniques in this study, by observation, in-depth interviews with 6 informant, and documentation study by taking a picture in the attractions of Goa Giri Putri. The data have been analyzed with descriptive qualitative data analysis techniques are broadly communicating, and systematic explanation of the data obtained in the field with the aim of obtaining a clear picture and objektif.

The result of this research is the role of local communities in the management of a tourist attraction Pura Goa Giri Putri is as pengemong / pengempon who have the responsibility to maintain and grow attractions Goa Giri Putri directly or indirectly such as participating maintain cleanliness, keeping tourist attraction Goa Giri Putri, keeping pemedek or tourists who visit and support the implementation of the current pujawali ceremony / ceremony at Pura Goa Giri Putri with managers and other stakeholders.

Keywords: Participation, Local Communities, Management, Tourist Attraction, Community Based Tourism

\section{PENDAHULUAN}

Pariwisata merupakan salah satu industri yang memiliki perkembangan begitu pesat di Bali. Dalam pengertiannya pariwisata adalah kegiatan melakukan perjalanan dengan tujuan mendapatkan kenikmatan, mencari kepuasan, mengetahui sesuatu, memperbaiki kesehatan, menikmati olahraga atau istirahat, menunaikan tugas, berziarah dan lain-lain (Spillane 1982). Dengan keberadaan industri pariwisata yang semakin berkembang membuat Pendapatan Asli Daerah (PAD) di beberapa daerah di Bali menjadi semakin meningkat. Seperti diketahui sektor pariwisata merupakan salah satu sektor penyumbang devisa negara terbesar ke-empat setelah sektor minyak bumi dan gas (BPS 2016). Banyak daerah yang mendapatkan kontribusi yang cukup dari adanya pariwisata di Bali seperti halnyaKabupaten Klungkung yang terkenal dengan wisata kuliner berupa serombotan. Keunikan lain dari klungkung yaitu adanya satu daerah yang menawarkan berbagai daya tarik wisata serta beragam potensi yang mampu menarik kunjungan wisatawan, daerah ini bernama Nusa Penia. Nusa Penida merupakan salah satu kecamatan yang ada di Kabupaten Klungkung dengan bentuk berupa pulau yang dibagi menjadi tiga bagian yaitu pulau Nusa Penida, pulau Nusa Ceningan dan pulau Nusa Lembongan.
Sebagian besar penduduknya bermata pencaharian sebagai petani rumput laut yang sekaligus menjadi sektor unggulan yang ada di Kecamatan Nusa Penida. Daya tarik wisata yang terdapat di Nusa Penida yaitu berupa pura dan juga ikan purba yang sering dikenal dengan sebutan "Sun Fish" atau Mola-mola. Di Nusa Penida terdapat sebuah pura yang yang cukup terkenal sebagai salah satu daya tarik wisata yang sering dikunjungi oleh wisatawan asing maupun lokal yaitu Pura Goa Giri Putri.

Pura Goa Giri Putri merupakan salah satu daya tarik wisata spiritual yang terletak di Desa Dinas Suana, Desa Pakraman Karang Sari. Sesuai dengan namanya pura ini dibangun ditengah goa yang cukup besar. Mengenai asal usul Pura Goa Giri Putri tidak pernah diketahui sebelumnya tentang awal berdirinya pura ini namun masyarakat sekitar meyakini bahwa pura ini merupakan bukti dari adanya kerajaan yang pernah bejaya di Nusa Penida.

Sebagai salah satu daya tarik wisata, pura ini dikelola oleh masyarakat sekitar dengan ketentuan adat yang telah dimiliki. Dalam pengelolaannya pengempon pura berperan langsung dalam melayani wisatawan yang datang maupun umat yang bertujuan untuk bersembahyang. Para pengempon pura yang dipilih oleh para Pemangku ( istilah yang sama dengan "mangku" )pura yang di ketuai oleh Mangku Gede Dharma sebagai pimpinan utama 
pura. Pengelolaan daya tarik wisata pura Goa Giri Putri hanya melibatkan para pemangku pura dan beberapa petinggi Desa Pakraman Karang Sari dalam pengelolaannya. Masyarakat sekitar pura juga belum berkontribusi secara maksimal dalam pengelolaan daya tarik wisata Pura Goa Giri Putri. Peran masyarakat dalam pengelolaan suatu daya tarik merupakan suatu bentuk pariwisata berkelanjutan, yang orientasi dalam industri pariwisata tidak hanya melihat keuntungan secara materi namun juga meningkatkan kualitas sosial disekitar daya tarik wisata Pura Goa Giri Putri.

Dari uraian diatas ada pun permasalahan yang ingin dipecahkan yaitu mengenai peran serta masyarakat lokal dalam pengelolaan daya tarik wisata Pura Goa Giri Putri yang bertujuan untuk mengetahui peran masyarakat lokal Desa Pakraman Karang Sari dalam pengelolaan daya tarik wisata Pura Goa Giri Putri.

\section{METODE PENELITIAN}

Lokasi penelitian ini dilaksanakan di Desa Pakraman Karang Sari, Desa Suana, Kecamatan Nusa Penida, Kabupaten Klungkung. Teknik pengumpulan data menggunakan wawancara, observasi, dan juga dokumentasi. Data yang terkumpul dianalisis menggunakan teknik analisis data deskriptif kualitatif yang menguraikan, menggambarkan, dan menjelaskan secara sistematis data yang diperoleh di lapangan dengan tujuan memperoleh gambaran yang jelas dan objektf.

\section{HASIL DAN PEMBAHASAN}

\subsection{Gambaran Umum Goa GiriPutri.}

Berdasarkan hasil observasi yang dilakukan di daya tarik wisata Pura Goa Giri Putri terdapat Pelinggih Apit Lawang sebagai akses masuk ke Goa. Cara mencapai Pelinggih Apit Lawang ini, pemedek ( orang yang berziarah dalam istilah hindu ) ataupun wisatawan harus berjalan kaki menaiki anak tangga yang cukup tinggi untuk sampai ke pintu goa. Sebelum memasuki mulut goa para pemedek atau wisatawan diwajibkan melakukan persembahyangan atau berdoa untuk meminta ijin akan memasuki Pura Goa Giri Putri tersebut. Di tempat ini terdapat tumpukan batu dan di tengah-tengah batu tersebut terdapat lubang yang digunakan sebagai pintu masuk ke areal dalam goa. Lubang tersebut tidaklah terlalu besar.
Di dalam goa dipenuhi dengan stalaktit yang terdapat diatas dinding goa. Inilah yang menyebabkan daya tarik wisata Pura Goa Giri Putri menarik dan tidak ada lagi di tempat lainnya. Terdapat beberapa aturan yang harus dipatuhi oleh orang yang ingin masuk ke daya tarik wisata Pura Goa Giri Putri, yaitu wisatawan diharuskan untuk memakai setidaknya kamben dan selendang ketika akan memasuki areal daya tarik wisata Pura Goa Giri Putri. Selain itu, yang terpenting adalah setiap orang yang sedang cuntaka/kotor (dalam artian terdapat keluarga yang meninggal) dan wanita sedang mengalami menstrurasi tidak diperbolehkan masuk ke areal daya tarik wisata Pura Goa Giri Putri. Di dalam Goa terdapat enam pelinggih / tempat persembahyangan yang berbeda-beda, yang mempunyai keunikankeunikan tersendiri dari masing-masing pelingih tersebut. Jalan untuk keluar goa, pemedek atau wisatawan tidak boleh kembali ke Jalan utama melainkan harus mengikuti jalur yang telah disediakan. Jalan keluar dari goa tersebut berada pada pelinggih terakhir dari Pura Goa Giri Putri. Jalan ini berada di balik goa dan jalannya sedikit memutar untuk menuju areal parkir.

\subsection{Pengelolaan Daya Tarik Wisata Pura Goa Giri Putri.}

Daya tarik wisata adalah segala sesuatu yang memiliki keunikan, keindahan, dan nilai yang berupa keanekaragaman kekayaan alam atau budaya dan hasil buatan manusia yang menjadi sasaran kunjungan wisatawan (UU Kepariwisataan No 10 th 2009).

Daya tarik wisata Pura Goa Giri Putri merupakan sebuah daya tarik wisata yang pengelolaannya dilakukan oleh masyarakat lokal. Pengertian pengelolaan adalah ilmu dan seni mengtatur proses pemanfaatan sumber daya manusia dan sumber-sumber lainnya secara efektif dan efisien untuk mencapai suatu tujuan (Hasibuan 2000). Dengan begitu, masyarakat-lah yang berhak mengelola daya tarik wisata Pura Goa Giri Putri.

Di Desa Pakraman Karang Sari ini, karena daya tarik wisata dan Pura Goa Giri Putri ini menjadi satu berupa kawasan spiritual maka yang memiliki tugas untuk mengelola daya tarik wisata tersebut adalah desa adat. Desa adat memiliki kewenangan untuk mengelola, merawat ataupun mengembangkan 
daya tarik wisata yang juga menjadi satu dengan tempat persembahyangan ini. Karena kepala desa adat adalah bendesa dan pengelola daya tarik wisata Pura Goa Giri Putri ini adalah desa adat, sehingga kepala pengelola daya tarik wisata Pura Goa Giri Putri ini secara tidak langsung adalah Bendesa Adat Karang Sari.

Pengelolaan daya tarik wisata Pura Goa Giri Putri oleh desa adat dilakukan semenjak tahun 2005. Sebelum tahun 2005 pengelolaan daya tarik wisata Pura Goa Giri Putri ini dilakukan oleh kumpulan masyarakat yang disebut dengan paibon. Anggota dari paibon yang mengelola daya tarik wisata Pura Goa Giri Putri ini sebelum pengelolaannya dilimpahkan ke Desa Pakraman Karang Sari dari tahun 2005 hingga sekarang. Pengelola daya tarik wisata Pura Goa Giri Putri atau masyarakat Desa Pakraman Karang Sari menyebut-nya pengemong daya tarik wisata Pura Goa Giri Putri ini dipilih pada forum pesangkepan/rapat umum dengan menggunakan sistem rolling setiap 2 tahun sekali, kecuali para pemangku yang sudah menjadi pinandita tidak menggunakan sistem rolling karena pemangku yang ngayahdi sebuah pura dalam kepercayaan Agama Hindu adalah seseorang yang memang diharuskan untuk tetap bertugas / ngayah dan melayani pemedek yang berkunjung ke sebuah pura. Dalam pelaksanaan nya, pemangku di daya tarik wisata Pura Goa Giri Putri ini menggunakan sistem shift. Para pemangku bertugas melayani pemedek atau wisatawan bergantian pagi dan siang harinya. Ketika waktu odalan/hari baik bagi umat Hindu tiba, seperti purnama, tilem dan hari baik lainnya semua pemangku akan bertugas dalam melayani pemedek atau wistawan yang datang. Pemangku-pemangku di daya tarik wisata Pura Goa Giri Putri ini dikepalai oleh seorang Mangku Gede dan dibawahnya ada Mangku Alit. Mangku Gede dan Mangku alit inilah yang memberikan arahan kepada pemangku lainnya dalam melayani pemedek ataupun wisatawan yang berkunjung ke daya tarik wisata Pura Goa Giri Putri ini.

Pengelola dan pemangku yang bertugas melayani pemedek dan wisatawan di daya tarik wisata Pura Goa Giri Putri ini menggunakan sistem ngayah, dalam sistem sosial masyarakat Hindu ngayah ini adalah seseorang bekerja dengan sukarela dan tidak menginginkan imbalan. Dalam pelaksanaaanya sitem ngayah ,pemangku dan pengelola daya tarik wisata Pura Goa Giri Putri memang tidak mendapatkan gaji, namun pengelola dan pemangku mendapatkan upah sebesar $75 \%$ dari sesari yang didapatkan. Sisa sesari sebesar 25\% akan dimasukkan ke kas daya tarik wisata Pura Goa Giri Putri. Selain dari sesari, kas yang dimiliki daya tarik wisata Pura Goa Giri Putri ini juga berasal dari punia atau sumbangan sukarela yang diberikan oleh para pemedek maupun para wisatawan yang berkunjung dan juga dari para donatur-donatur. Donatur ini dapat berupa perorangan atau instansi.

Untuk punia/sumbangan sukarela yang masuk ke kas daya tarik wisata Pura Goa Giri Putri akan dipakai untuk renovasi dan perbaikan fasilitas yang terdapat dalam daya tarik wisata Pura Goa Giri Putri, serta untuk membeli upakara / banten dan sarana upacara pada saat ada piodalan di Pura Goa Giri Putri. Selain dari punia, kas yang dimilik oleh daya tarik wisata juga berasal dari biaya masuk yang dibebankan terhadap wisatawan mancanegara sebesar Rp. 20.000,00.

\subsection{Peran Masyarakat dalam Pengelolaan Daya Tarik Wisata Goa Giri Putri.}

Masyarakat memiliki peranan besar dalam proses pemberdayaan masyarakat di daya tarik wisata Pura Goa Giri Putri. Seperti dalam pengertiannya, masyarakat adalahsuatu kesatuan hidup manusia yang berinteraksi menurut suatu sistem adat istiadat tertentu yang bersifat kontinyu dan terikat oleh suatu rasa identitas yang sama (Koentjaraningrat 1994). Masyarakat memiliki tanggung jawab yang besar dalam pengelolaan daya tarik wisata Pura Goa Giri Putri sebagai pariwisata yang berbasis masyarakat. Pada awal pengelolaan daya tarik wisata Pura Goa Giri Putri di tahun 2007, saat hari raya / pujawali Pura Goa Giri Putri, masayarakat dikenai urunan / sumbangan wajib sebesar Rp. 500.000,00 perkepala keluarga. Setelah itu hingga sekarang masyarakat Desa Pakraman Karang Sari tidak lagi dikenai urunan / sumbangan wajib tersebut karena kas pengelola daya tarik wisata Pura Goa Giri Putri ini cukup untuk pelaksanaan pengelolaan sehari-hari hingga perbaikan dan renovasi.

Untuk saat ini peran masyarakat Desa Pakraman Karang Sari di daya tarik wisata Pura Goa Giri Putri dibedakan menjadi dua, yaitu 
peran masyarakat secara langsung dan peran masyarakat secara tidak langsung. Peran adalah suatu kompleks pengharapan manusia terhadap caranya individu harus bersikap dan berbuat dalam situasi tertentuyang berdasarkan status dan fungsi sosialnya (Ahmadi 1982).

\section{A. Peran secara langsung.}

Peran masyarakat Desa Pakraman Karang Sari secara langsung adalah sebagai pengemong/pengempon yang memiliki tanggung jawab ikut merawat dan menjaga daya tarik wisata Pura Goa Giri Putri seperti ikut menjaga kebersihan, menjaga keamanan daya tarik wisata Pura Goa Giri Putri, menjaga pemedek atau wisatawan yang berkunjung dan mendukung pelaksanaan upacara ketika pujawali / hari raya di Pura Goa Giri Putri dengan ikut membantu pengelola dan pemangku dalam melayani pemedek dan wisatawan yang berkunjung. Peran aktif dan keikutsertaan masyarakat Desa Pakraman Karang Sari ini ketika hari raya / pujawali disaat ramainya para pemedek atau wisatawan yang berkunjung menandakan masyarakat Desa Pakraman Karang Sari andil yang besar dalam sistem pemberdayaan masyarakat di daya tarik wisata Goa Giri Putri. Pemberdayaan masyarakat adalah proses pembangunan di mana masyarakat berinisiatif untuk memulai proses kegiatan sosial untuk memperbaiki situasi dan kondisi diri sendiri. Pemberdayaan masyarakat hanya bisa terjadi apabila warganya ikut berpartisipasi. Suatu usaha hanya berhasil dinilai sebagai "pemberdayaan masyarakat" apabila kelompok komunitas atau masyarakat tersebut menjadi agen pembangunan atau dikenal juga sebagai subyek. Disini subyek merupakan motor penggerak, dan bukan penerima manfaat. Walaupun tidak semua masyarakat Desa Pakraman Karang Sari bertugas untuk mengelola daya tarik wisata Pura Goa Giri Putri, namun pengelola dari daya tarik wisata Pura Goa Giri Putri ini dipilih oleh Bendesa melalui pesangkepan / rapat umum.

\section{B. Peran Secara tidak langsung.}

Kelompok masyarakat yang tidak terpilih dalam rapat umum tersebut bukan berarti tidak memiliki peran dalam pengelolaan daya tarik wisata Pura Goa Giri Putri. Peran masyarakat yang tidak terpilih dalam rapat umum memiliki tanggung jawab sebagai penjaga kelestarian daya tarik wisata Pura Goa Giri Putri dan juga sebagai fasilitator bagi wisatawan atau pemedek yang ingin mengunjungi daya tarik wisata Pura Goa Giri Putri. Dengan begitu mayoritas masyarakat Desa Pakraman Karang Sari diberdayakan oleh daya tarik wisata Pura Goa Giri Putri. bahwa pemberdayaan masyarakat merupakan upaya untuk memandirikan masyarakat lewat perwujudan potensi kemampuan yang mereka miliki. Mandiri dalam artian memiliki potensi untuk mampu memecahkan masalah-masalah yang mereka hadapi, dan sanggup memenuhi kebutuhannya dengan tidak menggantungkan hidup mereka pada bantuan pihak luar, baik pemerintah maupun organisasi-organisasi nonpemerintah.

Daya tarik wisata Pura Goa Giri Putri sebagai daya tarik wisata minat khusus yang dikelola oleh masyarakat lokal secara mandiri tentunya akan membawa pengaruh terhadap masyarakat lokal. Karena tidak ada campur tangan dari pihak luar, baik pemerintah maupun swasta, interaksi yang terjadi langsung menyentuh dan melibatkan masyarakat dalam interaksi tersebut maka akan membawa berbagai pengaruh terhadap masyarakat lokal.

\section{KESIMPULAN}

\subsection{Simpulan.}

Dari hasil pembahasan diatas dapat disimpulkan bahwa peran masyarakat Desa pakraman Karang Sari dalam pengelolaan daya tarik wisata Goa Giri Putri ada dua, yaitu peran secara langsung dan tidak langsung. Peran secara langsung adalah sebagai pengemong/pengempon yang memiliki tanggung jawab ikut merawat dan menjaga daya tarik wisata Goa Giri Putri seperti ikut menjaga kebersihan, menjaga keamanan daya tarik wisata Pura Goa Giri Putri, menjaga pemedek atau wisatawan yang berkunjung dan mendukung pelaksanaan upacara ketika pujawali / hari raya di Pura Goa Giri Putri dengan ikut membantu pengelola dan pemangku pura dalam melayani pemedek dan wisatawan yang berkunjung. Secara tidak langsung adalah sebagai pengawas dan juga penjaga kelestarian sekitar pura dan juga sebagai fasilitator untuk para wisatawan dan juga pemedek yang ingin mengunjungi daya tarik wisata Pura Goa Giri Putri. sistem pengelolaan daya tarik wisata Pura Goa Giri 
Putri ini adalah sistem rolling, dimana pengelola dipilih dari masyarakat lokal Desa Pakraman Karang Sari dalam pesangkepan / rapat umum yang dipimpin oleh Bendesa Pakraman Karang Sari dan di-rolling / diganti setiap 2 tahun sekali. Selain itu besarnya kekuasaan yang dimiliki Bendesa Pakraman Karang Sari membuat kemungkinan terjadinya penyalahgunaan kekuasaan demi kepentingan pribadi akan semakin besar. Tidak adanya organisasi mandiri yang mengelola daya tarik wisata Pura Goa Giri Putri akan membuat sulit mengembangkan daya tarik wisata Pura Goa Giri Putri dan masyarakat tidak mendapatkan manfaat ataupun timbal balik dari pengembangan sebuah daya tarik wisata.

Kendala lainnya adalah masih kurangnya pengembangan daya tarik wisata yang bertujuan menarik wisatawan, seperti promosi secara langsung maupun tidak langsung dari daya tarik wisata Goa Giri Putri ini.

\subsection{Saran.}

Saran yang dapat penulis berikan kepada pihak pengelola adalah untuk meminimalkan kendala yang dihadapi dalam pengelolaan daya tarik wisata Pura Goa Giri Putri seperti pemberdayaan masyarakat sekitar dan membentuk organisasi yang di dalamnya terdapat orang-orang profesional dalam pengembangan daya tarik wisata dan fokus dalam mengelola daya tarik wisata Pura Goa Giri Putri sehingga nantinya ada kejelasan bagaimana arah pengembangan pariwisata dan dapat memberikan manfaat positif terhadap masyarakat lokal di daya tarik wisata Pura Goa Giri Putri.

\section{Daftar Pustaka:}

Ahmad, Abu. 1982. Sosiologi Pendidikan : Membahas Gejala Pendidikan Dalam Konteks Struktur Sosial Masyarakat. Jakarta : Binallmu.

Hasibuan, Malayu SP. 2000. Manajemen Sumber Daya Manusia. Yogyakarta : STIE YKPN.

Koentjaraningrat. 1994. Metode Penelitian Masyarakat. Jakarta : Gramedia Pustaka Utama.

Spillane, James j. 1982. Ekonomi Pariwisata, Sejarah, Dan Prospeknya. Yogyakarta : Kanisius.

Undang Undang RI No. 10 Tahun 2009 Tentang Kepariwisataan.

sumber lainnya :

www.bps.go.id (tanggal akses 16 juli 2016). 